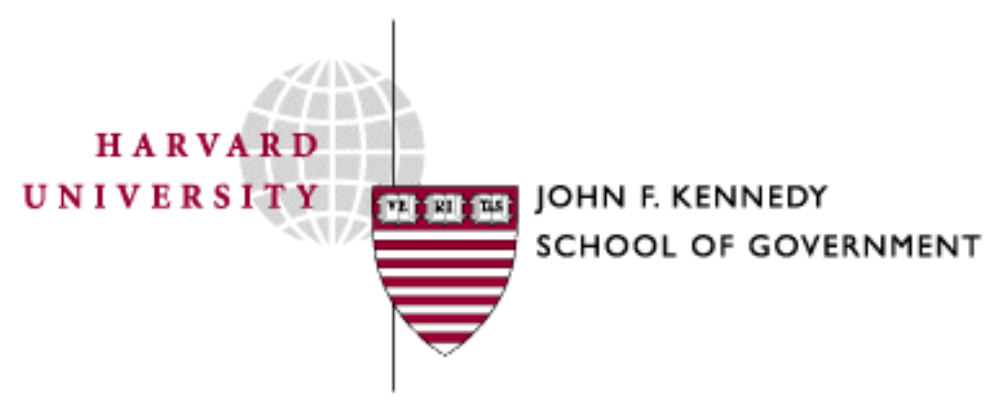

Faculty Research Working Papers Series

\title{
Facing the Fiscal Crises in State Governments: National Problem; National Responsibilities
}

\author{
Robert D. Behn and Elizabeth K. Keating
}

June 2004 (Revised September 2004)

RWP04-025

The views expressed in the KSG Faculty Research Working Paper Series are those of the author(s) and do not necessarily reflect those of the John F. Kennedy School of Government or Harvard University. Copyright belongs to the author(s). Papers may be downloaded for personal use only. 


\title{
Facing the Fiscal Crises in State Governments: National Problem; National Responsibilities
}

\author{
Robert D. Behn and Elizabeth K. Keating \\ The Taubman Center for State and Local Government \\ John F. Kennedy School of Government, Harvard University
}

Two-and-half years after the 2001 recession ended, the states — both individually and collectively - face hard fiscal times. "Despite an improving economy," the National Conference of State Legislators recently reported, "states still must close . . a \$36 billion [collective budget] gap in fiscal year 2005." Indeed, the states must continue to deal with a large disparity between the expenditures required to provide the different services that different citizens seek and the revenues that their current tax structures produce.

The states' problem, however, is not that merely that they were hit very hard by the recession of 2001 or that they have been recovering from it very slowly. The problem is deeper. As the national economy continues to grow, the states continue to face a serious financial mismatch between revenues and expenditures.

Indeed, given the realities of American federalism, state policymakers should prepare themselves to deal with tough fiscal times for the rest of the decade and (depending on what actions governments take) maybe longer. The financial trends are clear. The existing, built-in financial demands of the states' current responsibilities are growing more rapidly than are revenues. Thus, until we citizens make a fundamental change in our political thinking - either increasing the state taxes that we are willing to pay, or readjusting our expectations about the services we want state (and local) government to provide, or making some fundamental changes in intergovernmental responsibilities - state policymakers should expect the tough fiscal times to continue for years to come.

\section{The Fifty State Fiscal Crises}

The recession of 2001 brought with it — as recessions always do — an automatic drop in state revenues and an automatic increase in the demand for state services and thus for state spending. This latest recession was relatively brief and relatively shallow. Nevertheless, state revenues have recovered slowly while the demands for specific services, and thus for more spending, has hardly abated. For example, during FY 2003, 37 of the 50 states cut spending by almost $\$ 14.5$ billion after

The authors thank Alan Altshuler, Charles Euchner, Arnold Howitt, David Luberoff, Nicholas Johnson, and numerous other colleagues from for their advice and assistance in preparing this paper. 
their initial budgets were enacted. ${ }^{2}$ Indeed, the 2001 recession has revealed problems that will prove larger and longer lasting than usual.

In the summer of 2003, three economists - Brian Knight of Brown University, and Andrea Kusko and Laura Rubin of the Federal Reserve Board - concluded that "when measured as a percentage of GDP, the deficit in 2002 [in state and local government] was the largest on record." Indeed, they write, "the present fiscal crisis stands out in comparison with the two previous ones, mainly because of the sharpness of the fiscal deterioration in the face of a relatively shallow contraction in economic activity."

Similarly, in September 2003, Donald Boyd of the Nelson A. Rockefeller Institute of Government observed that "the fiscal crisis facing states is far worse than the condition of the nation's economy."

Unlike other nations with state or provincial subdivisions, the United States makes little effort to require its states to behave in similar ways. ${ }^{5}$ Indeed, the federal government encourages programmatic diversity. Thus, the states are free to provide the services that they believe appropriate and to impose the taxes that they believe necessary (although, unlike the federal government, they must balance their budgets ${ }^{6}$ ). For example, in FY 2002, Alaska spent 25 percent of its Gross State Product or $\$ 11,500$ per capita. In contrast, Nevada and Texas limited spending to just 8.9 percent of GSP, and Colorado spent just $\$ 3,100$ per capita. $^{7}$

Consequently, an examination of the aggregate data on state finances fails to capture what is happening in any particular state. In FY 2002, total state expenditures were $\$ 1.28$ trillion; yet half of this - \$643 billion — was accounted for by just eight states: California, Florida, Illinois, Michigan, New York, Ohio, Pennsylvania, and Texas. In contrast, the 15 fiscally smallest states together spent only $\$ 81$ billion - just 6 percent of the total, and the 23 fiscally smallest states spent, collectively, less than California. ${ }^{8}$ There is no one, uniform, nationwide, state fiscal crisis. Instead there are fifty different state fiscal crises - some small, some large, and each with its own unique characteristics.

\section{Whose Fault Is It?}

A variety of factors have contributed to the states' current problems. During the 1990s, the states both increased spending and cut taxes. And although they put more reserves into their rainyday funds, they didn't put in enough. Because they could both increase some services and cut some taxes, the states were not forced to think seriously about what would happen when economic growth slowed. Thus, many argue, the states' fiscal crises are the states' own fault. But why is it the states' own fault? Some argue that it is the states' own fault because they spent too much. Others argue that it is the states' own fault because they cut taxes too much. Indeed, there exist data to support both views.

Over two decades, 1983 to 2002, per-capita state spending grew significantly. From $\$ 1,450$ in 1983, median state per-capita expenditures tripled to $\$ 4,450$ in 2002. And the trends were the same for both the upper quartile and lower quartile states. Even when adjusted for inflation, median per-capita expenditures (in 2002 dollars) increased by over 70 percent from $\$ 2,590$ in 1983 to $\$ 4,450$ in 2002. ${ }^{9}$ (See Exhibit 1, page 16.) Clearly the states are spending more - on a per-capita basis. 
At the same time that per-capita spending was increasing, the states were also cutting taxes. In every year from 1994 to 2000, reports the Center on Budget and Policy Priorities, the net result of all state tax-code changes was to reduce state tax revenues. And the cumulative impact of these state tax cuts was a net 8.2 percent reduction in state tax revenue - which reduced state tax revenues in FY 2002 by over $\$ 40$ billion. $^{10}$

The states, of course, could have done more. Some observers have emphasized that the states have been unable to correct the underlying structural problem with their tax systems. For example, Raymond Scheppach, executive director of the National Governors Association, points to the "longrun structural decline in [state] revenues." The states developed their tax systems "for the manufacturing economy of the 1950s," says Scheppach, "not the service-oriented, high technology, international economy of the 21 st century." $" 1$

The most obvious problem is with the state sales tax, which was based on the implicit assumption that the "sale" occurred in a physical exchange during which a customer personally gave some money to a retailer, and, in return, the retailer personally gave the customer a product. Since then, however, the nature of the "sale" has been modified in two important ways. First, many of the sales are for services not products, and in many states, the sales tax mostly covers products not services. The Federation of Tax Administrators has arranged the various services sold into 164 different categories. ${ }^{12}$ Predictably, the number of services taxed by the different states ranges quite broadly; Washington state taxes all 164, while its neighbor Oregon taxes none. ${ }^{13}$ Second, many sales are transacted at a distance - with orders placed and products or services delivered by mail, over the phone, or via the Internet. And, again, in many states, the sales tax does not cover many of these purchases.

Others argue that the fault is not with the states but with the federal government for putting pressures on the states in a variety of ways. Although the federal government provides the states with various forms of direct and indirect aid, it also imposes costs on the states. Iris Lav of the Center on Budget and Policy Priorities concludes that the effect of the federal government's "positive impacts" on state and local governments of $\$ 467$ billion in 2004 was reduced by "negative impacts" of $\$ 153$ billion. For 2007, Lav predicts the positive impacts will increase slightly to $\$ 477$ billion but the negative impacts will jump to $\$ 220$ billion. The net positive impact will thus drop from $\$ 314$ billion in 2004 to $\$ 256$ billion in $2007 .{ }^{14}$

One way that the federal government imposes costs on the states is through unfunded mandates - costs that it requires the states to incur. The National Conference of State Legislators (NCSL) estimates that such unfunded mandates are costing the states \$29 billion for FY 2004 and will cost them $\$ 34$ billion in FY 2005. For example, NCSL argues that the states' drug costs for people who are eligible for both Medicare and Medicaid will be $\$ 6.6$ billion in FY 2005. ${ }^{15}$

In reality, however, the federal government imposes few real "mandates." Congress does, however, place multiple requirements and conditions on the funds that it provides for many intergovernmental programs. It creates and modifies such programs and then offers the states money for their implementation - provided that the states comply with a variety of conditions to obtain these funds. Initially, the states find this deal attractive, if only because the benefits are obvious, and the costs appear small. Often, when Congress creates an intergovernmental program, a state may already have a similar program, or a state may be thinking about undertaking a similar initiative. So the additional funds appear to be a windfall. Moreover, there inevitably exists a local stakeholder 
organization that aggressively lobbies its legislature both to take the money and to comply with the requirements. This local group, a branch of a national organization that aggressively and successfully lobbied Congress to create or revise the program, wants to be sure that its own state implements this program.

Thus the states - although they are not constitutionally or legally required to participate in most intergovernmental programs - are pushed to do so. In total, a quarter of state spending comes from the federal government. ${ }^{16}$ Thus the Congress will continue to enjoy its ability to impose multiple conditions and requirements on any funding it offers for intergovernmental activities.

\section{The Persistent Impact of the 2001 Recession}

The immediate cause of the state's fiscal crisis was the national economy. Throughout the last half of the 1990s, the economy was growing and so were state tax revenues, masking these underlying problems. According to Elizabeth Davis and Nicholas Jenny of the Rockefeller Institute of Government, the growth in state tax revenues in the second quarter (April-June) over the second quarter of the previous year was 7.1 percent in 1995, 7.3 percent in 1996, 6.2 percent in 1997, 9.7 percent in 1998, 5.0 percent in 1999, and 11.4 percent in 2000. "The personal income tax has been the engine driving this extraordinary growth," write Davis and Jenny, who focus attention on the second-quarter because states with income taxes set their filing date to be April 15. ${ }^{17}$ Over six years (1994 to 2000), second-quarter state tax revenues grew by 57 percent.

This growth in tax revenues during the late 1990s meant that the states were able to cut taxes as a percent of GSP and at the same time to increase per-capita spending. But in late 2000, when the economy began to slow and then, in 2001, when it entered and exited the nine-month recession, ${ }^{18}$ many sources of state revenues automatically dropped, ${ }^{19}$ while some state expenditures automatically grew. More significantly, even after the recession was officially over, state revenues failed to rebound.

This trend is striking when compared with earlier recessions. In the 1980-1982 recession, state revenues dropped 2 percent. In the 1990-91 recession, state revenues dropped 3.5 percent. In the 2001 recession — which was the mildest of the three — state revenues dropped 7.4 percent. $^{20}$ Although the recession (as measured by the National Bureau of Economic Research in terms of changes in Gross Domestic Product) was both shorter and shallower than the two previous ones ${ }^{21}$ - its impact on state revenues was much larger. (See Exhibit 2, page 17.) Moreover, the recession's impact has lingered. In FY 2003, 21 states spent less than they had for FY $2002 .{ }^{22}$

Moreover, this both brief and relatively shallow recession has had a significant impact on employment. As a result of the 1990-1991 recession, private-sector employment dropped 2 percent and then returned to its pre-recession level after 38 months. The 2001 recession, however, caused a drop in employment of 3 percent. Moreover, in May 2004, 39 months after the its pre-recession peak in February 2001, private-sector employment was still almost 2 percent below its pre-recession level. (See Exhibit 3, page 18.) And although employment did increase over the most recent four months (from January to May 2004) by a million, it is still nearly 2 million short of the pre-recession level. ${ }^{23}$ 
In the second half of 2003, state tax revenues did begin to grow again. The Fiscal Studies Program of the Rockefeller Institute of Government reports that, in the third quarter of 2003, state tax revenues grew for the first time since the recession. Indeed, state tax revenues grew in the last two quarters of 2003 and in the first quarter of 2004. ${ }^{24}$ (See Exhibit 4, page 19.)

The basis of comparison from which such quarterly revenue growth is measured is the revenue collected in the same quarter in the previous year - which has been, of course, down from the prerecession levels. Thus, although state tax revenues have recently increased compared with the prior year, they have not returned to their pre-recession levels. Indeed, on a per-capita basis, reports the Rockefeller Institute, state tax revenues in the first quarter of 2004 were still roughly 85 percent of their pre-recession peak. ${ }^{25}$ (See Exhibit 5, page 20.)

If the states look at the recent growth in their revenues (compared with last year), they may no longer feel the pressure to continue to make spending adjustments during the fiscal year to balance their 2005 budgets. Nevertheless, they do not yet have the resources to return to the pre-recession level of services that they provided in 2000 .

\section{How the States Responded}

In 2000, as the economy first weakened and the early-warning signs began to appear, the states did not react very quickly. Nevertheless, as the recession began and revenues dropped, every state employed some combination of the five basic options that they possess to close a budget gap. They (1) drew down reserves; (2) increased taxes; (3) found new sources of revenue; (4) cut expenditures; and (5) borrowed. ${ }^{26}$

(1) Draw down reserves: Forty-eight states have established some kind of formal rainy-day fund. ${ }^{27}$ During the years when revenues are growing faster than expenditures, a state can accumulate reserves. Then, when the growth in revenues slackens or disappears, the state can tap these reserves to minimize the necessity of cutting expenditures.

Between the recession of 1990-91 and the recession of 2001, this is what happened. During the 1990s, the states slowly but steadily built up their end-of-the-fiscal-year balances. At the end of FY 1992, state balances totaled \$3.1 billion (or 1.1 percent of expenditures). By the end of FY 2000, these balances had grown to $\$ 48.8$ billion (or 10.4 percent of expenditures). Then, as the economy began to slow down and their revenues dropped even faster, the states tapped these reserves to compensate for the gap between revenues and expenditures. By the end of 2003, total reserves were back down to just $\$ 6.4$ billion (or 1.3 percent of expenditures). ${ }^{28}$

(2) Increase taxes: In response to the 2001 recession and its aftermath, states did, on balance, raise taxes - but not all states and not all taxes.

For example, for FY 2002, 29 states changed their taxes (and fees) to create a net revenue gain of $\$ 304$ million. In 14 of these states, these changes in tax laws produced a net increase in their revenues, while in 15 , the consequence of these changes was a net loss of tax revenue. Twenty states acted to reduce revenues from one or more of their taxes. Three states acted to increase revenues from their personal income tax, while 12 cut this tax — for a net loss to state government of $\$ 671$ million. ${ }^{29}$ 
For FY 2003, however, only seven states cut their net tax revenues, while 23 states raised them - for a net increase of $\$ 8.0$ billion. Five states cut their personal income taxes, while 11 increased them for a net gain of $\$ 1.1$ billion. But the biggest tax increase - $\$ 3.0$ billion - came from the 19 states that increased their tobacco taxes. ${ }^{30}$

For FY 2004, state tax-law changes produced a net revenue increase of $\$ 9.5$ billion. Two states cut net tax revenues, while 35 states enacted laws to increase their total tax revenues including a $\$ 2.6$ million net increase in sales tax revenue, and a $\$ 2.5$ million net increase in total revenue from the personal income tax. ${ }^{31}$

The states have not, however, raised taxes as much in the wake of the 2001 recession as they did in response to the recession of 1990-1991. For FY 1991, the states increased taxes to generate $\$ 10$ billion, and for FY 1992, they increased taxes again to generate an additional $\$ 15$ billion. Thus, in two quick years (FY 1991 and FY 1992), the states added \$25 billion in taxes. Over five years, FY 1990-FY 1994, the states raised taxes by $\$ 36$ billion. In contrast, for the three years since the recession hit in 2001, the states raised taxes to generate just $\$ 18$ billion. Elaine Maag of the Urban Institute and David Merriman of Loyola University-Chicago observe: "During the recession that began in July 1990, policy makers quickly increased taxes to bring budgets into balance. In the recession that begin in April 2001, policymakers shunned significant tax policy changes.",32 Moreover, they note, "[total] state tax revenues were $\$ 32$ billion lower in 2002 than in 2001, the first year over year revenue decline in recent history." "33

(3) Find new sources of revenue: For FY 2004, half the states raised their "fees," formally categorized as "user charges" rather than taxes. Nicholas Jenny and James Orsi of the Rockefeller Institute observe that increasing fees is "one of the most notable methods [that] states used to help close the big gaps that they confronted in their fiscal 2004 budgets." 34 For example, the College Board reported that tuition and fees at public universities and two-year colleges jumped 14 percent for the 2003-2004 academic year. ${ }^{35}$

For FY 2002, 10 states increased fees (and one state cut them) for a total revenue increase of $\$ 182$ million. For FY 2003, 14 states increased fees by a total of $\$ 819$ million (with New York's increase of $\$ 430$ million accounting for more than half of the total). In FY 2004, 25 states raised fees to produce a total of $\$ 1.8$ billion (with Illinois increasing its fees by $\$ 414$ million, Michigan by $\$ 284$ million, New York by $\$ 235$ million, and Massachusetts by $\$ 218$ million.) And state governments' focus on fees continues; in their budget proposals for FY 2005, 20 governors proposed to increase fees by a total of $\$ 1.5$ billion (including $\$ 306$ million in California, $\$ 232$ million in New Jersey, and $\$ 578$ million in New York). ${ }^{36}$ (See Exhibit 6, page 21.)

In addition, the states have increasingly used the payments that they receive from the tobacco settlement to cope with their financial crises. The General Accounting Office reports that the states used 20 percent of their FY 2002 tobacco revenues to cover that year's budget shortfalls and 36 percent of these revenues for the same purpose in FY 2003. Further, the states told GAO that they expected to use 54 percent of their tobacco revenues to balance their FY 2004 budgets. $^{37}$

Naturally, given that state budgets already benefit from some of the profits from lotteries and casino gambling, state officials are tempted to add or expand this source of revenue. And some states have done so, though perhaps not as widely or rapidly as the breadth and depth of the fiscal crises 
might suggest. ${ }^{38}$ Indeed, even before the 2001 recession hit, state revenues from their lotteries were leveling off. ${ }^{39}$

(4) Cut expenditures: On the spending side, the states were forced - after they had adopted their FY 2003 budget — to make additional cuts totaling \$14.5 billion; 28 states implemented across-the-board spending cuts, 20 employed furloughs, 8 used early retirement, and 17 made layoffs. Still, in FY 2003, 31 states spent more from their general fund than they had during FY 2002. These increases where relatively modest with only North Dakota (up 15\%) and West Virginia (up 10\%) making double-digit expansions. Meanwhile, the other 19 states actually reduced expenditures (in current not constant dollars) so that the net result (for all 50 states) was a total increase in general-fund spending of only $0.3 \%{ }^{40}$ Thus (given that the inflation rate for this fiscal year was over 2.3 percent $^{41}$ ) in constant dollars, total state expenditures actually declined.

(5) Borrow: In many state governments, the budget is essentially an operating, cash budget (not an accrual budget). Consequently, for a state, a budget is balanced when cash inflows equal (or exceed) cash outflows. At the end of the fiscal year, one way to ensure that the year's cash budget is balanced is to borrow - putting money into the current year's cash budget, while imposing costs on future year's cash budget.

For example, 14 states have sought to take immediate advantage of the funds they obtained from their 1997 and 1998 settlements with the tobacco companies. ${ }^{42}$ The tobacco companies will pay the states $\$ 245$ billion over 25 years. Fourteen states have "sold" their future tobacco revenues in a process called "securitization." In FY 2001 and FY 2002, eight states used this strategy to generate one-time payments totaling $\$ 4.7$ billion. In FY 2003, five states got $\$ 6.5$ billion from securitization. Indeed, in FY 2003, the $\$ 6.5$ billion state revenues from securitization exceeded the $\$ 6.3$ billion obtained directly from the tobacco companies. ${ }^{43}$

Of course, securitization of future tobacco funds is just another way to borrow from the future. The states are selling bonds backed by future payments from tobacco companies. It is analogous identical to selling bonds (to cover current expenditures) and pledging to pay them off with the revenues from an increase in the sales tax. There is, however, an important difference; the states passed the risk - that the tobacco companies will have sufficient profits to meet their future obligations - to the bond holders. ${ }^{44}$

\section{The Streamlined Sales Tax Project}

The states have undertaken one important, long-term collaboration: the Streamlined Sales Tax Project. In 2000, 34 states launched this effort to fix one of their underlying tax problems: the inability of a state to impose its sales tax (or its use tax) on goods purchased from outside of its borders. ${ }^{45}$ In 2001, Donald Bruce and William Fox of the University of Tennessee estimated that the inability of state and local governments to tax interstate sales made just over the Internet would cost them $\$ 45$ billion in 2006 and $\$ 55$ billion in $2011 .^{46}$

In 1992, the Supreme Court decided that the states did not have intrinsic authority to impose sales taxes on goods or services delivered to consumers within their borders by retailers that did not have physical presence there. The Court did, however, explicitly note that Congress possessed "the ultimate power" to resolve this question and was "now free to decide" it. To make it easier for multi- 
state retailers to comply with different state and local sales-tax requirements, and thus to prod Congress to permit the states to impose such taxes, 34 states have banded together to create the Streamlined Sales and Use Tax Agreement.

The states have not yet completed their work on this project, and it is not certain that, even when they do, Congress will act. Nevertheless, it is a potentially significant initiative that would not tap into the federal treasury or require the states to enact any tax increases.

\section{The Structural Gap}

The current fiscal crises of the states is not a temporary blip that will disappear as the economy improves. A variety of factors will prevent the states from recovering as fast as the nation's or their own economies. Two trends are particularly important:

(1) A state's revenues will not grow as fast as its economy.

(2) Two of state government's primary responsibilities - education and health care - have been consuming more and more of the economy's Gross Domestic Product, and thus more and more of the states' budgets.

During the late 1990s, tax revenues in some states grew faster than the state's underlying economy. In those states that had an income tax that included a significant tax on dividends and/or capital gains, state income-tax revenues did briefly grow faster than the economy as a whole. ${ }^{47}$ But most state tax systems are designed so that revenues grow (in usual economic circumstances) more slowly than its Gross State Product. For example, if a state taxes the sales of most goods but few services, its sales-tax revenues will not increase with the growth of the services sector. ${ }^{48}$

Many people believe that this is acceptable - even desirable. The difficulty comes when our individual and collective desire for services exceed our individual and collective willingness to pay for them. And this appears to be the case because of our recent, collective willingness to reject political candidates who refuse to take the anti-tax pledge, because of the nature of the production of education and health-care, and because of our desire for these two (and other) services.

For FY 2003, elementary and secondary education accounted for 22 percent of state spending, Medicaid for 21 percent, and higher education for 11 percent. ${ }^{49}$ Thus, education and Medicaid consume 55 percent of the states' budgets — with Medicaid having risen from 13 percent in $1990 .{ }^{50}$

Moreover, for three reasons, health-care and education continue to demand an increasing share of our economy (and are likely to continue to do so for the foreseeable future). First, like other components of the service sector, health care and education have not been able to improve the productivity of their workers at the same rate as the manufacturing sector. ${ }^{51}$ Second, as we citizens and consumers become wealthier, we seek to consume as individuals more education and more health care as a percent of our personal expenditures - and thus as a percent of GDP. Third, the researchand-development component of the health-care sector keeps creating new - and expensive treatments, thus further increasing our desire to consume more of this service. Meanwhile, the research component of various human institutions keeps creating new knowledge — knowledge that 
employees, to be productive in the U.S. and global economy, have to master through more and more years of education.

As a result of the combination of these three trends, health care and education have - by a variety of different measures - become a bigger component of the nation's economy.

* From 1980 through 2002, the nation's per-capita expenditures for health care have grown faster than inflation. In 15 of these 23 years, per-capita health-care expenditures grew at more than twice the rate of inflation. Over these 23 years, the consumer price index increased by 137 percent, while per-capita expenditures on health care grew by 479 percent. $^{52}$ (See Exhibit 7, pages 22-23.)

* As a share of Gross Domestic Product, the nation's expenditures for health care have also grown significantly. In 1960, the health care consumed 5.1 percent of GDP. By 1990 it was up to 12.0 percent, and by 2002, it was at 14.9 percent. The Center for Medicare and Medicaid Services projects that by 2013 health care will consume 18.4 percent of GDP. ${ }^{53}$ (See Exhibit 8, page 24.)

* Over the last forty years, employment in the education and health sectors has also grown significantly. In 1960, one of every 18 nonagricultural employees was working in education and health services; today, that is one in eight. ${ }^{54}$

As we citizens demand more and higher quality education and as we demand more and higher quality health care, we drive up the costs of these services. At the same time, we also demand fewer taxes and lower tax rates. The result is a growing gap between the services we demand and the taxes we are willing to provide.

Some have labeled this a "structural problem" of state government; others protest that to call this a structural problem is to mis-diagnose what is really a political problem: a mismatch between our collective desire for public services and our collective willingness to pay the corresponding taxes. Whether you think the problem is structural or political — whether you think the solution is less spending or more taxes - the mismatch is real. And, two factors ensuring that this mismatch will not quickly disappear are Medicaid and the component of Medicaid that funds long-term custodial care.

\section{Medicaid}

In FY 2002, the nation spent $\$ 257$ billion on Medicaid. Not all of this spending came from state revenues. The state share of this intergovernmental program varies significantly from 50 percent for the states with the highest per-capita income down to approximately 25 percent.

Each state must comply with a variety of minimum requirements established by the federal government (if it chooses to participate in the program at all), but it can also offer a variety of additional services. For example, North Dakota devotes 62 percent of its Medicaid spending to longterm care. In contrast, Georgia puts only 23 percent of its Medicaid resources into long-term care. ${ }^{55}$ Thus, there isn't really one, national Medicaid program. Instead we have fifty, quite different Medicaid programs. 
Medicaid is the second largest and fastest growing component of state budgets. In fact, the growth in the cost of Medicaid will, by itself, continue to create a large, structural problem for state budgets. In FY 2002, over 50 million Americans - one of every six citizens - received some assistance from Medicaid. Twenty-two percent of all children have full Medicaid coverage, as do 37 percent of the poor, 60 percent of nursing home residents, and 15 percent of those on Medicare. One quarter of Medicaid's beneficiaries are elderly or disabled; but this one-quarter receives nearly threequarters (70 percent) of the benefits.

In recent years, the growth rate in the Medicaid enrollment rate has escalated. From December 1997 through December 2002, Medicaid enrollment grew from 30.7 million to 39.6 million - 29 percent in just five years. Between December 2000 and December 2002, enrollment grew by 19 percent. $^{56}$

As a share of Gross Domestic Product, federal expenditures for Medicaid have grown from 0.1 percent in 1966, to 0.5 percent in 1976, to 1.1 percent in 1992, to 1.5 percent in 2003 . Moreover, the Congressional Budget Office projects federal spending for Medicaid to grow at an annual rate of 7.2 percent over the next decade. During the next few years, however, CBO anticipates that federal spending on Medicaid will be relatively low. (One reason is that the extra $\$ 10$ billion that Congress provided the states for Medicaid for FYs 2003 and 2004 will end; this extra support raised the FY 2004 base from which increases are calculated while its disappearance reduces federal Medicaid expenditures in FY 2005 and beyond. A second reason is that "the new Medicare drug benefit will relieve Medicaid of having to provide drug benefits to individuals who are eligible for both programs." After 2007, however, federal spending on Medicaid will then "increase to an average of nearly 9 percent annually." As a result, concludes $\mathrm{CBO}$, it will grow to 1.9 percent of GDP in $2014 .^{57}$

For FY 2005, reports the National Association of State Budget Officers, the states' governors recommended a net 12.1 percent increase in Medicaid spending from their own state revenues. ${ }^{58}$ Whatever the states themselves continue to do to cut spending or raise revenues, they will have to confront the reality that annual increases in Medicaid costs will absorb much of these budget savings.

\section{Long-term Custodial Care}

A large and growing component of Medicaid expenditures goes for long-term care, over half of which is for nursing-home care. The rest goes for community and home care. Indeed, of the nation's total spending on nursing homes, Medicaid pays for half. Moreover, of all nursing-home bed days, Medicaid recipients occupy 70 percent. $^{59}$

In FY 2000, long-term care for the elderly, blind, and disabled represented 35 percent of the \$206 billion spent on Medicaid. ${ }^{60}$ In FY 2002, Medicaid expenditures per elderly, blind, or disabled individual averaged more than five times the expenditures per child or parent (or pregnant woman). Indeed, that year, the average per-elderly-enrollee expenditure on long-term care alone was over six times the total expenditures per child and nearly five times the total expenditure per parent. ${ }^{61}$

Moreover, expenditures for nursing-home care have grown significantly in recent years and will continue to grow in the future. From 1990 to 2002, the nation's expenditures for nursing homes nearly doubled - from $\$ 52.7$ billion to $\$ 103.2$ billion. The Center for Medicare and Medicaid 
Services (CMS) projects nursing home expenditures will grow another 79 percent to $\$ 184.8$ billion by $2013 .^{62}$ (See Exhibit 9, page 25. )

Further, the share of these nursing-home services paid by Medicaid increased from 44 percent in 1990 to 49 percent in 2002 - and is projected by CMS to increase to 55 percent in 2013. From 1990 to 2002, the state's share of Medicaid's nursing home costs doubled from $\$ 10.2$ billion to $\$ 20.5$ billion. And, predicts CMS, they will double again by 2013 - to $\$ 41.1$ billion. $^{63}$

As the nation's population continues to age, Medicaid's built-in costs for long-term custodial care will continue to rise - and continue to be a larger and larger component of state expenditures.

\section{What Should the Federal Government Do?}

Indeed, what can the federal government do? The menu of actions is actually quite limited. The federal government can:

(1) Do nothing;

(2) Provide general financial assistance;

(3) Refrain from imposing as many requirements and restrictions;

(4) Accept more of a financial commitment for funding particular intergovernmental programs;

(5) Reallocate the responsibilities in our federal system.

The only option that may appeal immediately to many of the federal government's policymakers is to do nothing.

In the spring of 2003, Congress did provide $\$ 20$ billion in financial relief to state governments for fiscal years 2003 and 2004. It designated $\$ 10$ billion to increase the Medicaid reimbursement formula and half for general relief. It did so, however, because a few determined members of an evenly divided Congress used their leverage near the very end of a long negotiation over the $\$ 320$ billion tax-cut bill to obtain this one-time financial relief for the states. Congressional leaders have given no hint that they will renew this assistance.

Morever, Congress is unlikely to rethink in any fundamental, philosophical way its general propensity to condition intergovernmental programs with numerous requirements and conditions. Every time Congress creates or modifies an intergovernmental program, it will decide anew how much it will leverage each federal dollar to generate even more state spending and how many conditions it will impose. ${ }^{64}$

Thus, the question of what the federal government should do about the states' fiscal crises comes down to the details of specific intergovernmental responsibilities. Will Congress be willing to give the states more flexibility to tax different economic activities, and will it be willing to revise the financial and operational responsibilities for several key intergovernmental programs? 


\section{Taxing Internet Access and Interstate Sales}

In two important ways, Congress prevents the states from imposing taxes that they have, historically. First, Congress has acted to prevent forty states from imposing taxes on Internet access. Second, Congress has not acted to help the states tax mail-order and Internet sales across state borders.

For decades, state and municipal governments have taxed access to telephone lines. By 1998, ten states had imposed similar taxes on access to the Internet. That year, Congress acted to prevent more state and municipalities from imposing such Internet access taxes (though it did permit those states that had already enacted such taxes to continue them). This moratorium has been continuously debated by Congress, with some arguing for a much broader exemption for taxes on Internet services, including the elimination of the exception for the ten states that now have access taxes. The Congressional Budget Offices estimated that extending the ban to all states "would impose significant costs on some state and local governments," and that these "direct costs . . . would probably total between $\$ 80$ million and $\$ 120$ million annually." 65

Those firms engaged in providing Internet access or interstate sales would prefer not to be taxed. And they will continue to lobby Congress aggressively. If Congress is serious about the future of our federal system, however, it could - at little or no cost to its own programs, revenues, and policy concerns - explicitly assent to the states' ability to impose these two taxes. Indeed, for Congress, these tax issues create a simple test: Is the federal government willing to think seriously about how to make fiscal federalism work in the twenty-first century?

\section{Funding Intergovernmental Programs}

In FY 2004, the federal government will provide $\$ 418$ billion in grants to state and local governments, of which $\$ 381$ billion, or 91 percent, will go to programs in four big categories: transportation ( $\$ 43$ billion); education, training, employment, and social services ( $\$ 57$ billion); income security ( $\$ 88$ billion); and health (\$192 billion). ${ }^{66}$

Congress, however, is unlikely to revamp significantly the basic structure of its approach to many intergovernmental programs including transportation and income security (as well as homeland security). The intergovernmental division of responsibilities for transportation has been relatively stable for years; and although funding levels may vary, the basic relationship is not likely to be transformed in the near future. In 1996, welfare reform revised the relationship between the state and federal governments on income security; this effort continues to be subject to debate with pressures in Congress to reduce — not increase — federal funding. ${ }^{67}$ Homeland security is another issue on the intergovernmental agenda - with governors and mayors being repeatedly annoyed whenever the color-coded warning level jumps from yellow to orange. Despite this annoyance, even a significant change in the federal government's support for state and local homeland security activities will do little to close the structural gap.

In contrast, the intergovernmental arrangements for elementary and secondary education have been subject to much recent discussion and debate. The federal government's $\$ 57$ billion in funding for education covers a variety of activities, from the National Endowments for the Arts to college housing loans. The two biggest programs within this category - $\$ 9$ billion for special education, and 
$\$ 14$ billion for education for the disadvantaged - do, however, go directly for elementary and secondary education. Moreover, these are precisely the programs about which the states are most concerned.

And, of course, the biggest intergovernmental program is Medicaid. In FY 2004, it accounts for $\$ 177$ billion - or 42 percent — of the federal government's contributions to state and local programs. $^{68}$

\section{Elementary and Secondary Education}

In 1975, when Congress enacted the first federal legislation on special education, the states thought they had a deal. Although the federal government's contribution would start at a modest 5 percent, the "state entitlement" was to increase to 40 percent by FY 1982. ${ }^{69}$ Congress has never come close to fulfilling its part of the bargain. (For FY 2005, the administration has proposed funding that would increase the federal government's commitment to 20 percent. $^{70}$ )

This helps explain why state officials are so wary of the No Child Left Behind Act. Legislators in Ohio, Utah, and Virginia have been particularly critical of this legislation and are threatening not to participate. Their reasoning is clear: The federal government is providing little money but imposing significant requirements. Indeed, to receive its allocation of federal funds, a state has to add numerous new expenditures to its own budget. For example, a study done for the Ohio Department of Education concluded that implementing No Child Left Behind would cost the state $\$ 1.49$ billion over the next decade, with the federal government providing only $\$ 44$ million, leaving the state to fund the remaining $\$ 1.44$ billion. ${ }^{71}$ Others contend that federal funding is adequate to cover the requirements imposed by this legislation. ${ }^{72}$

The debate over funding is really over what requirements to assign to the No Child Left Behind Act. Those who focus on the testing requirements in the legislation conclude that federal funding easily covers this cost. Those who see the legislation requiring states not only to test but also to meet a variety of new and higher standards for both teachers and students calculate cost estimates that are significantly higher.

Many in state and local government think that Congress enjoys claiming credit for doing wonderful things that make important constituencies happy while leaving the states and municipalities to pick up the bill. If the federal government was serious about helping the nation improve elementary and secondary education - for students with and without disabilities — it would do more than pass laws, establish targets, require reports, and impose regulations. The federal government would also provide significant funding.

\section{Medicaid and Long-Term Custodial Care}

In 1965, Congress enacted two major health-care programs: Medicare, a federal program (administered by the Social Security Administration) to provide health insurance for the elderly and disabled, and Medicaid, an intergovernmental program funded by both the federal government and states (and administered by the states) to provide health insurance for the poor. Since then, however, 
the distinction has blurred: The size of the elderly population has grown significantly, and many of the elderly are also poor.

Moreover, Medicare does not cover nursing-home services and other forms of long-term custodial care, which are not really "medical" services. Medicaid, however, does cover such services for people who are indigent. As a consequence, elderly individuals may enter a nursing home, spend all of their retirement resources on this custodial service, become officially indigent, and thus are eligible for Medicaid - and for Medicaid's coverage of their nursing-home costs.

This was not ever envisioned, discussed, or debated in 1965 when Congress created the two programs. Lynn Etheredge and Judith Moore of George Washington University note that "Medicaid's expansion into this [long-term care] role came about more by default - because there were populations with very large assistance needs and there was no other program for them - than as a result of a national plan."73

As a result, Medicaid has become a very big problem for current and future state budgets. The underlying macro trends that affect the states' Medicaid expenditures - and, in particular, the states' Medicaid expenditures for long-term care - are pushing up Medicaid spending at a rate faster than other budget categories. ${ }^{74}$ And society's various efforts to control the costs of all health care have not been particularly successful. ${ }^{75}$ Thus, the cost of health care "will likely continue to outstrip growth in the overall U.S. economy by a sizable margin for the foreseeable future," conclude Bradley Strunk and Paul Ginsburg of the Center for Studying Health System Change. "Unless policymakers become more willing to increase public [tax] revenues more rapidly than incomes, increased spending for medical care will crowd out other public spending priorities." 76

Further, key trends are working to push up Medicaid's spending on long-term care. ${ }^{77}$ The number of elderly is increasing and the number of very elderly (those over 85 years) is increasing even more rapidly. And the pressures to improve the quality of long-term care may neutralize the pressures to control costs, if not override them. ${ }^{78}$

Removing long-term care from Medicaid will not, as a single measure, eliminate the structural gap in state budgets. Nevertheless, doing so would have a significant impact on the states' ability to provide other Medicaid services for the non-elderly indigent as well as to improve education, and other public programs. Indeed, the states cannot eliminate their recurring deficits unless they can deal with Medicaid and its funding of long-term custodial care. Medicaid may not have been the biggest driver of the states' financial problems over the past several years. Nevertheless, it is and will continue to be one of the biggest obstacles to ending the continual cycle of spending cuts and tax increases in the states' annual budget deliberations.

\section{Redefining Federal Responsibilities}

In 1908, Woodrow Wilson observed that "the cardinal question of our constitutional system" is the relationship between the states and the federal government. "Every successive stage of our political and economic development gives it a new aspect, makes it a new question," continued Wilson. And thus, "no definition either of statesmen or of judges has ever quieted or decided it." For, wrote Wilson, "the subject-matter of that definition" — the issues that drive this fundamental, 
constitutional question — "is constantly changing" and thus the relationship between the states and the federal government "cannot, indeed, be settled by the opinion of any one generation."

In 1965, Congress changed the relationship between the states and the federal government when it created the Medicaid program. In 1975, when it created a national special-education program, and, in 2002, when it enacted the No Child Left Behind Act, Congress again changed this relationship. The addition of these new "subject matters" — and their associated costs — has significantly stressed the relationship. And, although the federal government's demands on state education policy have galled numerous state officials, Medicaid is the "new aspect" that is creating the greatest financial pressure on the states.

Today, health care is the newest question of American federalism. As a result, numerous observers have offered new definitions for the health-care relationship. "It is time to rethink the allocation of responsibility between states and the federal government in coverage policy" for health care suggest three researchers, John Holahan and Alan Weil of the Urban Institute, and Joshua Wiener of RTI. Moreover, they write: "A fundamental conclusion from the evidence is that increasing the federal role in financing coverage is necessary." "80 Similarly, Lynn Etheredge and Judith Moore of George Washington University call for "a new state-federal partnership" for Medicaid. Cataloguing the problems caused by "the outdated Medicaid statute," Etheredge and Moore suggest the need for "a national long-term care strategy" that could include "a new federal matching formula." $" 81$

Indeed, Congress could completely redefine the responsibilities for health care within our federal system. Given that long-term custodial care is not "health" care as we traditionally think of it, Congress could detach it from Medicaid. By doing so - by removing the responsibility for longterm custodial care from Medicaid, by eliminating the confusion between medical care and custodial care - Congress could simultaneously provide significant financial assistance to the states.

Will Congress be willing to rethink the funding of Medicaid and of long-term custodial care? If Congress fails to revise in some fundamental way who should set policies for Medicaid and for long-term custodial care and who should pay for them, the fiscal crises of the states will inevitably continue to be a large problem.

Over a century after Wilson concluded his book on Constitutional Government in the United States with a chapter on "The States and the Federal Government," the nature of American federalism has, as Wilson predicted, continued to evolve. Indeed, we have little choice. We will continue to redefine "the relation of the states to the federal government." This is a given. What is not clear is whether we will do this unconsciously and haphazardly, or carefully and thoughtfully.

This is our effort to make the evolution in federalism a little more careful, a little more thoughtful. 


\section{Exhibit 1}

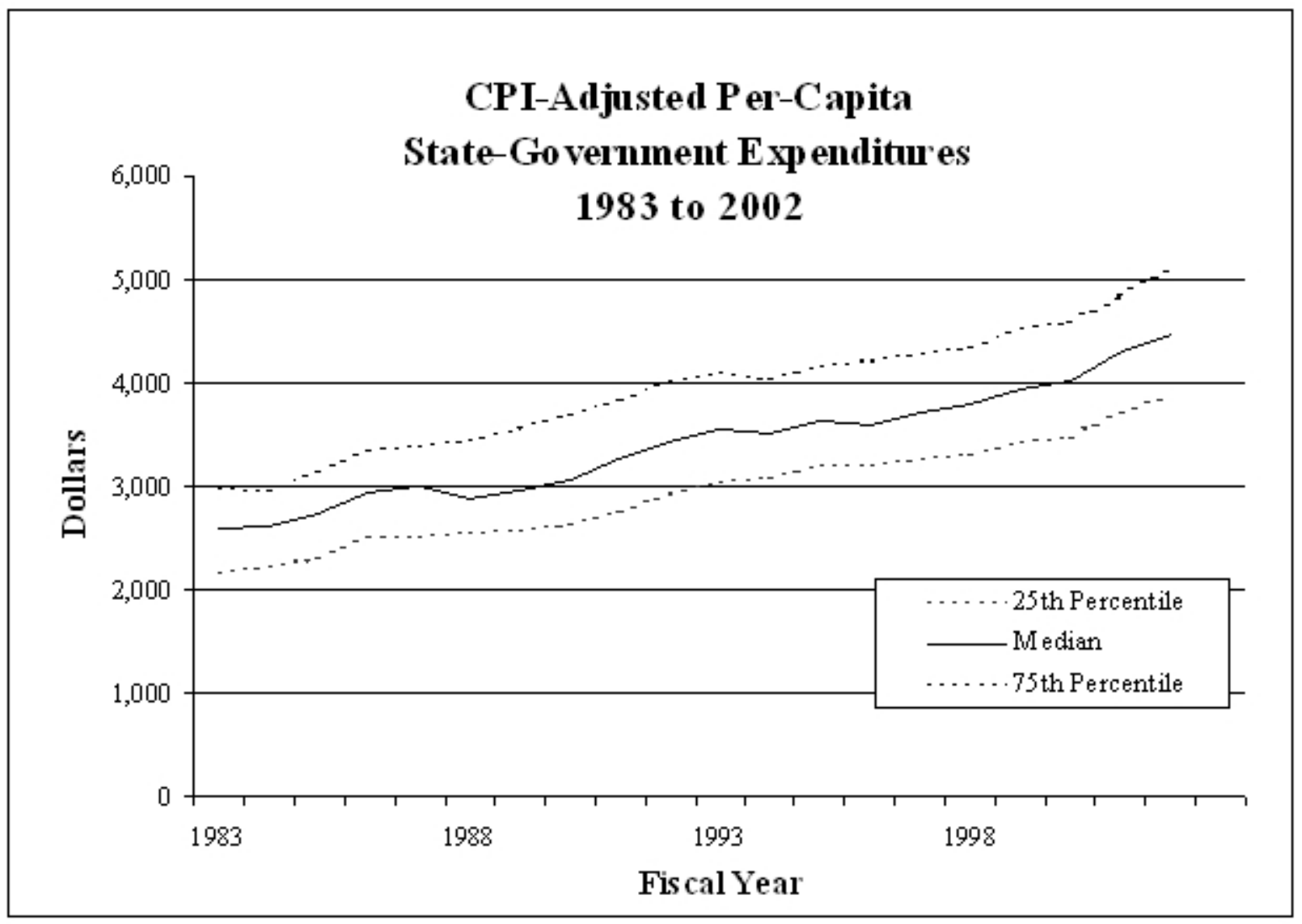

Source: These data on state spending per capita were calculated from data obtained from the Bureau of Economic Analysis and the Census Bureau (both in the U.S. Department of Commerce). The state expenditure data can be found at http://www.census.gov/govs/ www/estimate.html. The state population data can be found at http://eire.census.gov/ popest/estimates.php. 


\section{Exhibit 2}

\begin{tabular}{||l|c|c||}
\hline \multicolumn{3}{||c||}{$\begin{array}{l}\text { The Impact of the Three Most Recent Recessions } \\
\text { on Real, Per-Capita GDP and on State Tax Revenues }\end{array}$} \\
\hline \hline $\begin{array}{l}\text { Recession } \\
\text { Period }\end{array}$ & $\begin{array}{c}\text { Change in Real } \\
\text { Per-Capita GDP }\end{array}$ & $\begin{array}{c}\text { Change in Per-Capita } \\
\text { State Tax Revenues }\end{array}$ \\
\hline $1980-82$ & $-3.0 \%$ & $-2.0 \%$ \\
\hline $1990-91$ & $-1.8 \%$ & $-3.5 \%$ \\
\hline 2001 & $-0.7 \%$ & $-7.4 \%$ \\
\hline
\end{tabular}

Source: $\quad$ Donald Boyd, The Current State Fiscal Crisis and its Aftermath, Publication \#4138 (Washington, D.C.: Kaiser Commission on Medicaid and the Uninsured, September 2003), p. 2. (Boyd adjusted the data for legislative changes.) 


\section{Exhibit 3}

\begin{tabular}{|c|c|c|c|c|}
\hline \multicolumn{5}{|c|}{ The Impact of the Last Three Recessions on Private-Sector Employment } \\
\hline \multirow[b]{2}{*}{ Employment Level } & \multicolumn{2}{|c|}{ 1990-1991 Recession } & \multicolumn{2}{|c|}{2001 Recession } \\
\hline & Date & $\begin{array}{l}\text { Employment } \\
\text { in millions }\end{array}$ & Date & $\begin{array}{l}\text { Employment } \\
\text { in millions }\end{array}$ \\
\hline Pre-Recession Peak & March 1990 & 91.3 & February 2001 & 111.6 \\
\hline The Following Low & February 1992 & 89.6 & July 2003 & 108.2 \\
\hline Return to Peak & May 1993 & 91.6 & April 2004* & $109.4^{*}$ \\
\hline
\end{tabular}

* The data for April 2004 are the latest available and are still preliminary.

\section{Total Private-Sector Employment, January 1994 to May 2004}

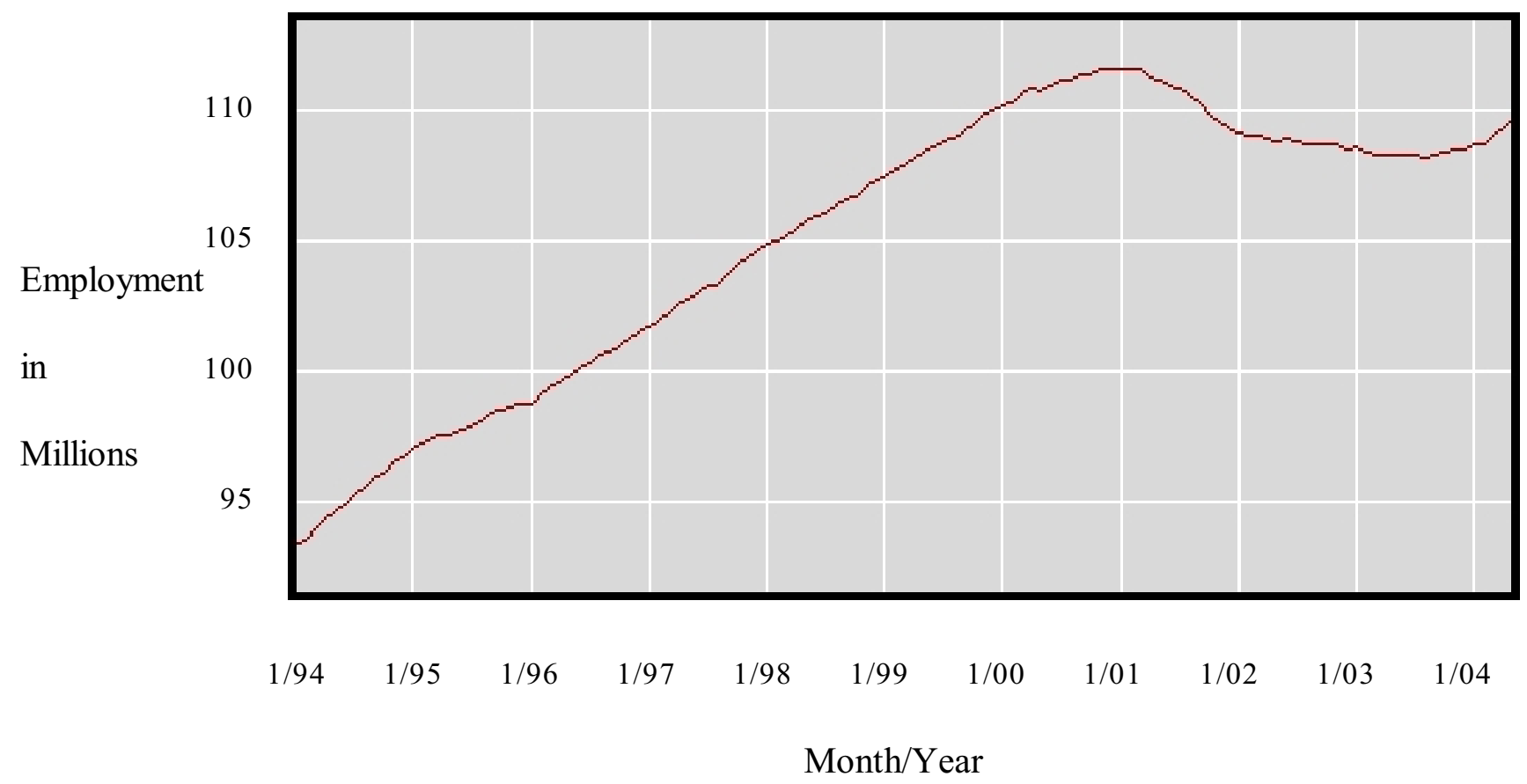

Source: Bureau of Labor Statistics, Current Employment Statistics Survey, Total Private Employment (Seasonally Adjusted) CES0500000001. Visited (6-16-2004) at http://data. bls.gov/cgi-bin/surveymost (through http://data.bls.gov/cgi-bin/surveymost?ce). 


\section{Exhibit 4}

\section{Year-Over-Year Change in Total State Tax Collections Adjusted for Legislation and Inflation}

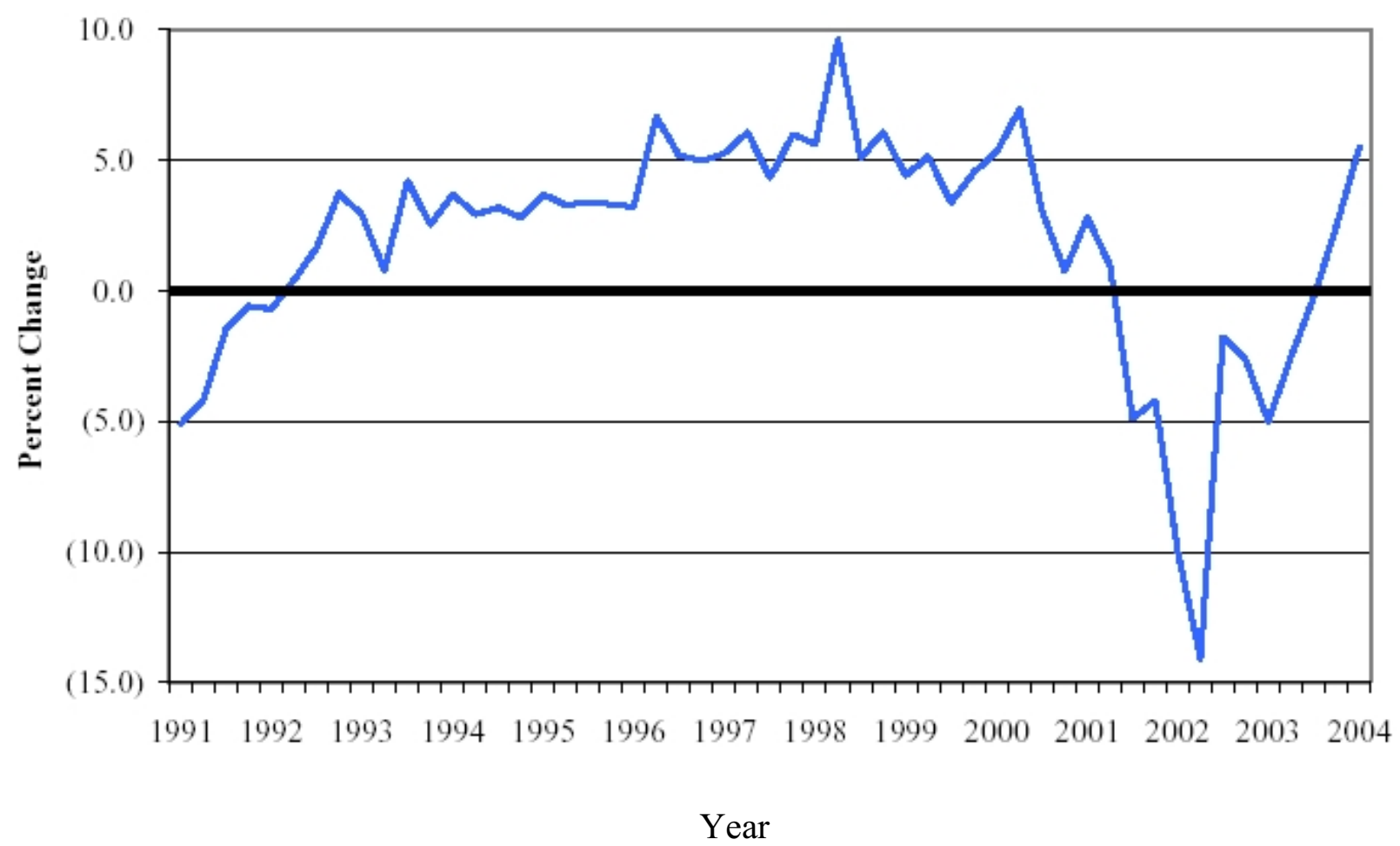

Source: Nicholas W. Jenny, State Tax Revenue Growth Gains Momentum, The Rockefeller Institute State Fiscal News, vol. 4, no. 3, May 2004, p. 1. (Reproduced with permission.) 


\section{Exhibit 5}

Per-Capita State Tax Revenue, Indexed to 1991 Adjusted for Legislation and Inflation

Four-Quarter Moving Average

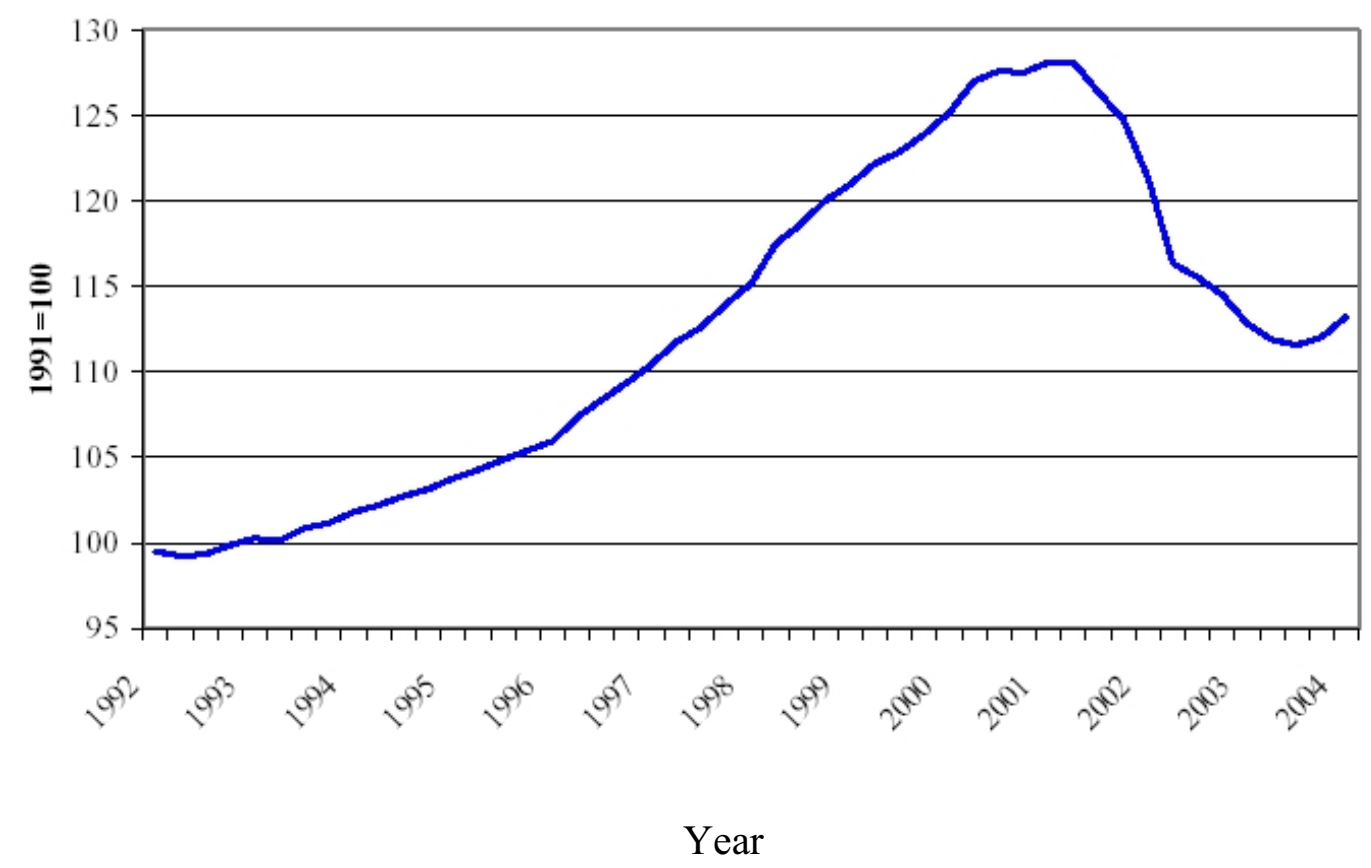

Source: $\quad$ Nicholas W. Jenny, State Tax Revenue Growth Gains Momentum, The Rockefeller Institute State Fiscal News, vol. 4, no. 3, May 2004, p. 2. (Reproduced with permission.) 


\section{Exhibit 6}

\begin{tabular}{||l|c|c|l|c||}
\hline \multicolumn{5}{|c||}{$\begin{array}{c}\text { State Fee Increases, FY 2002-2005 } \\
\text { (in millions of dollars) }\end{array}$} \\
\hline \hline \multirow{2}{*}{ Year } & $\begin{array}{c}\text { Number of } \\
\text { States Raising } \\
\text { Fees }\end{array}$ & $\begin{array}{c}\text { Total Amount } \\
\text { Generated by } \\
\text { Increasing Fees }\end{array}$ & The State with the Biggest Increase \\
\cline { 4 - 6 } & 11 & 182 & State & Amount \\
\hline \hline 2002 & 14 & 819 & New York & 430 \\
\hline 2003 & 25 & 1,809 & Illinois & 414 \\
\hline 2004 & 20 & 1,494 & New York & 578 \\
\hline
\end{tabular}

Source: National Governors Association and National Association of State Budget Officers, The Fiscal Survey of the States, December 2001, November 2002, December 2003, April 2004 (Washington, D.C.: National Governors Association and National Association of State Budget Officers, 2001, 2002, 2003, 2004). 


\section{Exhibit 7}

\begin{tabular}{|c|c|c|c|c|}
\hline \multicolumn{5}{|c|}{$\begin{array}{c}\text { Percent Annual Increases in Per-Capita, National Health Expenditures (NHE) } \\
\text { vs. Increase in Consumer Price Index (CPI), 1980-2002 }\end{array}$} \\
\hline \multicolumn{2}{|c|}{ Year } & Increase in CPI & Increase in $\mathrm{NHE}$ & $\begin{array}{l}\text { Ratio: NHE Increase/ } \\
\text { CPI Increase }\end{array}$ \\
\hline \multicolumn{2}{|l|}{1980} & $13.5 \%$ & $13.7 \%$ & 1.0 \\
\hline \multicolumn{2}{|l|}{1981} & $10.3 \%$ & $14.8 \%$ & 1.4 \\
\hline \multicolumn{2}{|l|}{1982} & $6.2 \%$ & $11.5 \%$ & 1.9 \\
\hline \multicolumn{2}{|c|}{1983} & $3.2 \%$ & $9.1 \%$ & 2.8 \\
\hline \multicolumn{2}{|c|}{1984} & $4.3 \%$ & $9.3 \%$ & 2.2 \\
\hline \multicolumn{2}{|c|}{1985} & $3.6 \%$ & $8.4 \%$ & 2.3 \\
\hline \multicolumn{2}{|l|}{1986} & $1.9 \%$ & $6.1 \%$ & 3.2 \\
\hline \multicolumn{2}{|l|}{1987} & $3.6 \%$ & $7.9 \%$ & 2.2 \\
\hline \multicolumn{2}{|l|}{1988} & $1.9 \%$ & $11.0 \%$ & 5.8 \\
\hline \multicolumn{2}{|l|}{1989} & $3.6 \%$ & $10.5 \%$ & 2.9 \\
\hline \multicolumn{2}{|l|}{1990} & $4.1 \%$ & $10.5 \%$ & 2.6 \\
\hline \multicolumn{2}{|c|}{1991} & $4.2 \%$ & $8.3 \%$ & 2.0 \\
\hline \multicolumn{2}{|l|}{1992} & $3.0 \%$ & $7.3 \%$ & 2.4 \\
\hline \multicolumn{2}{|l|}{1993} & $3.0 \%$ & $6.2 \%$ & 2.1 \\
\hline \multicolumn{2}{|l|}{1994} & $2.6 \%$ & $4.5 \%$ & 1.7 \\
\hline \multicolumn{2}{|l|}{1995} & $2.8 \%$ & $4.6 \%$ & 1.6 \\
\hline \multicolumn{2}{|c|}{1996} & $3.0 \%$ & $4.0 \%$ & 1.3 \\
\hline \multicolumn{2}{|l|}{1997} & $2.3 \%$ & $4.2 \%$ & 1.8 \\
\hline \multicolumn{2}{|l|}{1998} & $1.6 \%$ & $4.3 \%$ & 2.7 \\
\hline \multicolumn{2}{|l|}{1999} & $2.2 \%$ & $5.3 \%$ & 2.4 \\
\hline \multicolumn{2}{|l|}{2000} & $3.4 \%$ & $6.1 \%$ & 1.8 \\
\hline \multicolumn{2}{|l|}{2001} & $2.8 \%$ & $7.5 \%$ & 2.7 \\
\hline \multicolumn{2}{|l|}{2002} & $1.6 \%$ & $8.3 \%$ & 5.2 \\
\hline \multirow{2}{*}{$\begin{array}{l}\text { 23-Year } \\
\text { Growth }\end{array}$} & Ave. & $3.9 \%$ & $8.0 \%$ & 2.4 \\
\hline & Total & $136.6 \%$ & $478.9 \%$ & \\
\hline
\end{tabular}




\section{Exhibit 7 (continued)}

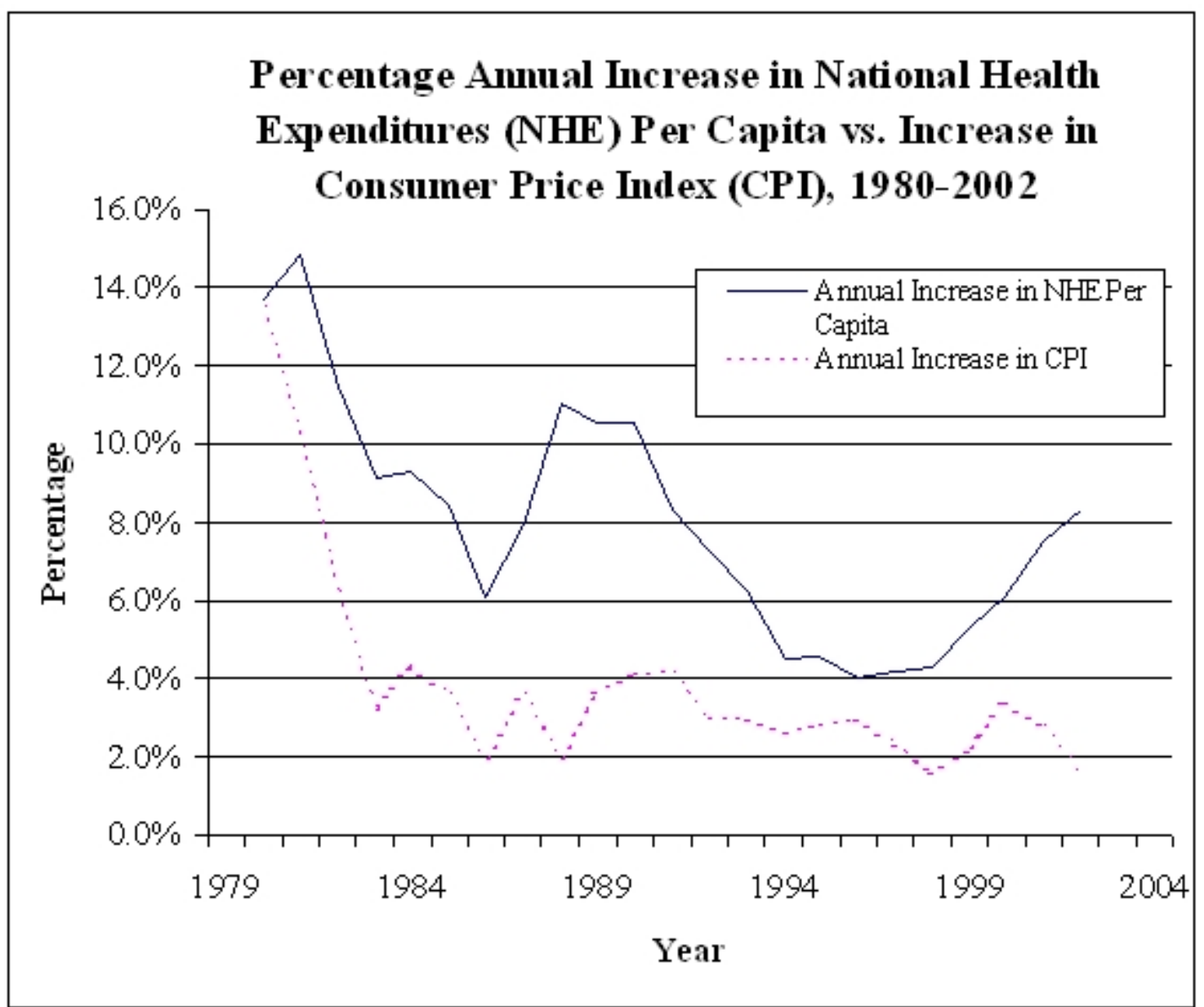

Source: Janet Lundy, Benjamin Finder, and Gary Claxton, Trends and Indicators in the Changing Health Care Marketplace, 2004 Update (Menlo Park, Calif.: Kaiser Family Foundation, April 2004), Exhibit 1.3, p. 6. http://www.kff.org/insurance/7031/index.cfm. 


\section{Exhibit 8}

\begin{tabular}{|c|c|}
\hline \multicolumn{2}{|c|}{$\begin{array}{c}\text { National Health Expenditures } \\
\text { as a Share of Gross Domestic Product } \\
1960-2013\end{array}$} \\
\hline Calendar Year & $\begin{array}{l}\text { Health Expenditures } \\
\text { as a Percent of GDP }\end{array}$ \\
\hline 1960 & 5.1 \\
\hline 1970 & 7.0 \\
\hline 1980 & 8.8 \\
\hline 1990 & 12.0 \\
\hline 2000 & 13.3 \\
\hline 2001 & 14.1 \\
\hline 2002 & 14.9 \\
\hline 2003 & $15.3 *$ \\
\hline 2004 & $15.5 *$ \\
\hline 2005 & $15.7 *$ \\
\hline 2006 & $16.0 *$ \\
\hline 2007 & $16.4 *$ \\
\hline 2008 & $16.7 *$ \\
\hline 2009 & $17.1 *$ \\
\hline 2010 & $17.4 *$ \\
\hline 2011 & $17.8 *$ \\
\hline 2012 & $18.1 *$ \\
\hline 2013 & $18.4 *$ \\
\hline
\end{tabular}

* Projected

Sources: Janet Lundy, Benjamin Finder, and Gary Claxton, Trends and Indicators in the Changing Health Care Marketplace, 2004 Update (Menlo Park, Calif: Kaiser Family Foundation, April 2004), Exhibit 1.1 ( http://www.kff.org/insurance/7031/index.cfm ); Office of the Actuary, Center for Medicare and Medicaid Services, "National Health Care Expenditures Projections: 2003-2013," Table 1. http://www.cms.hhs.gov/statistics/nhe/projections2003/proj2003.pdf. 


\section{Exhibit 9}

\begin{tabular}{|c|c|c|c|c|c|}
\hline \multicolumn{6}{|c|}{$\begin{array}{c}\text { Nursing Home Care Expenditures } \\
1990,1998-2013\end{array}$} \\
\hline \multirow{3}{*}{$\begin{array}{l}\text { Calendar } \\
\text { Year }\end{array}$} & \multicolumn{5}{|c|}{$\begin{array}{l}\text { Nursing Home Care Expenditures } \\
\text { (Dollars in Billions) }\end{array}$} \\
\hline & \multirow[b]{2}{*}{ Total } & \multicolumn{2}{|c|}{ Medicaid } & \multicolumn{2}{|c|}{ State \& Local } \\
\hline & & Amount & $\begin{array}{l}\text { Percent of } \\
\text { Total }\end{array}$ & Amount & $\begin{array}{l}\text { Percent of } \\
\text { Medicaid }\end{array}$ \\
\hline 1990 & $\$ 52.7$ & $\$ 23.2$ & $44.0 \%$ & $\$ 10.2$ & $44.0 \%$ \\
\hline 1998 & $\$ 89.1$ & $\$ 40.1$ & $45.0 \%$ & $\$ 17.2$ & $42.9 \%$ \\
\hline 1999 & $\$ 89.6$ & $\$ 41.8$ & $46.7 \%$ & $\$ 17.9$ & $42.8 \%$ \\
\hline 2000 & $\$ 93.8$ & $\$ 41.6$ & $44.4 \%$ & $\$ 18.5$ & $44.5 \%$ \\
\hline 2001 & $\$ 99.1$ & $\$ 46.9$ & $47.3 \%$ & $\$ 18.9$ & $40.3 \%$ \\
\hline 2002 & $\$ 103.2$ & $\$ 50.9$ & $49.3 \%$ & $\$ 20.5$ & $40.3 \%$ \\
\hline 2003 & $\$ 107.0$ & $\$ 54.1$ & $50.6 \%$ & $\$ 21.9$ & $40.5 \%$ \\
\hline 2004 & $\$ 111.7$ & $\$ 57.1$ & $51.1 \%$ & $\$ 23.1$ & $40.5 \%$ \\
\hline 2005 & $\$ 116.9$ & $\$ 60.6$ & $51.8 \%$ & $\$ 24.5$ & $40.4 \%$ \\
\hline 2006 & $\$ 123.3$ & $\$ 64.4$ & $52.2 \%$ & $\$ 26.1$ & $40.5 \%$ \\
\hline 2007 & $\$ 130.2$ & $\$ 68.6$ & $52.7 \%$ & $\$ 27.8$ & $40.5 \%$ \\
\hline 2008 & $\$ 137.8$ & $\$ 73.1$ & $53.0 \%$ & $\$ 29.6$ & $40.5 \%$ \\
\hline 2009 & $\$ 146.1$ & $\$ 78.1$ & $53.5 \%$ & $\$ 31.6$ & $40.5 \%$ \\
\hline 2010 & $\$ 155.0$ & $\$ 83.4$ & $53.8 \%$ & $\$ 33.7$ & $40.4 \%$ \\
\hline 2011 & $\$ 164.4$ & $\$ 89.1$ & $54.2 \%$ & $\$ 36.0$ & $40.4 \%$ \\
\hline 2012 & $\$ 174.3$ & $\$ 95.2$ & $54.6 \%$ & $\$ 38.5$ & $40.4 \%$ \\
\hline 2013 & $\$ 184.8$ & $\$ 101.8$ & $55.1 \%$ & $\$ 41.1$ & $40.4 \%$ \\
\hline
\end{tabular}

Numbers for 2003-2013 are projections.

Source: Office of the Actuary, Center for Medicare and Medicaid Services, "National Health Care Expenditures Projections: 2003-2013,” Table 13. http://www.cms.hhs.gov/statistics/nhe/ projections-2003/proj2003.pdf. 


\section{Notes}

1. "Mandate monitor: Mandates on the Move," NCSL NEWS, April 30, 2004. http://www.ncsl. org/programs/press/2004/pr040430b.htm.

2. National Governors Association and National Association of State Budget Officers, The Fiscal Survey of the States, June 2003 (Washington, D.C.: National Governors Association and National Association of State Budget Officers, 2003), p. ix.

See also "Tough Economic Times Remain for States," National Governors Association Press Release, June 26, 2003. http://www.nga.org/nga/newsRoom/pressReleaseDetailPrint/1,1422,5631, 00.html, visited 10-31-03.

3. Brian Knight, Andrea Kusko, and Laura Rubin, "Problems and Prospects for State and Local Governments," State Tax Notes, August 2003, pp. 427, 435.

4. Donald Boyd, The Current State Fiscal Crisis and its Aftermath, Publication \#4138 (Washington, D.C.: Kaiser Commission on Medicaid and the Uninsured, September 2003), p. 1.

5. For a discussion of how the states are different, see: National Association of State Budget Officers, "Budgeting Amid Fiscal Uncertainty: Ensuring Budget Stability by Focusing on the Long Term," 2004, particularly p. 14.

6. All states except Vermont have some legal requirement for a balanced budget. The exact nature and strictness of this requirement varies significantly, however. See: Richard Briffault, Balancing Acts: The Reality Behind State Balanced Budget Requirements (New York: The Twentieth Century Fund Press, 1996).

7. These data on state spending as a percent of Gross State Product and per capita were calculated from data obtained from the Bureau of Economic Analysis and the Census Bureau (both in the U.S. Department of Commerce). The state expenditure data can be found at http://www.census.gov/govs/ www/estimate.html. The data on GDP can be found at http://www.bea.doc.gov/bea/regional/gsp. $\mathrm{htm}$. The state population data can be found at http://eire.census.gov/popest/estimates.php.

8. Ibid.

9. Ibid.

10. Nicholas Johnson, "The State Tax Cuts of the 1990s, The Current Revenue Crisis, and Implications for State Services," Center on Budget and Policy Priorities (November 18, 2002), pp. $1,5,21$.

11. Raymond C. Scheppach, "From statehouse to poorhouse," The San Diego Union-Tribune, July 13, 2003, p. G1.

12. http://www.taxadmin.org/fta/pub/services/services.html.

13. Steven Daniels, Fiscal Crisis in State Governments: A Focus on 13 Western States, WRDC Public Policy Information Brief No. 1 (Logan, Utah: Western Rural Development Center, July 2003), 


\section{p. 7.}

14. Iris J. Lav, "Piling on Problems: How Federal Policies Affect State Fiscal Conditions," National Tax Journal, vol. 56, no. 3 (September 2003), pp. 535-554.

15. Mandate Monitor, vol. 1, issue 1 (revised, March 31, 2004), pp. 1, 2. http://www.ncsl.org/ programs/press/mandatemonitor.pdf.

16. National Association of State Budget Officers, "Budgeting Amid Fiscal Uncertainty: Ensuring Budget Stability by Focusing on the Long Term," 2004, p. 9.

17. Elizabeth I. Davis and Nicholas W. Jenny, "Can We Call It a 'Surprise" the Sixth Time It Happens?" State Revenue Report, The Nelson A. Rockefeller Institute of Government, No. 41 (September 2000), pp. 2, 4.

18. The National Bureau of Economic Research dates the 2001 recession as beginning in March and ending in November. http://release.nber.org/july2003.html.

19. Elizabeth I. Davis and Nicholas W. Jenny, "Weakest State Tax Revenue Growth in Over Seven Years," State Revenue Report, The Nelson A. Rockefeller Institute of Government, No. 43 (March 2001).

20. Donald Boyd, The Current State Fiscal Crisis and its Aftermath, Publication \#4138 (Washington, D.C.: Kaiser Commission on Medicaid and the Uninsured, September 2003), p. 2. (Boyd adjusted these data for legislative changes.)

Note that one reason that the revenues dropped so much from this pre-recession peak is because the revenue increases just prior to the recession were (for several states) quite significant and unusual.

21. William Nordhaus of Yale University has called it "the mildest recession of the postwar period." William D. Nordhaus, "The Mildest Recession: Output, Profits, and Stock Prices as the U. S. Emerges from the 2001 Recession," Cowles Foundation for Research in Economics at Yale University, Cowles Foundation Discussion Paper No. 1368, May 2002, p. 4.

22. National Association of State Budget Officers, "Budgeting Amid Fiscal Uncertainty: Ensuring Budget Stability by Focusing on the Long Term," 2004, pp. 5, 6.

23. Bureau of Labor Statistics, Current Employment Statistics Survey, Total Private Employment (Seasonally Adjusted) CES0500000001. http://data.bls.gov/cgi-bin/surveymost?ce.

24. Nicholas W. Jenny, State Tax Revenue Growth Gains Momentum, The Rockefeller Institute State Fiscal News, vol. 4, no. 3, May 2004, p. 1, Figure 1. These growth comparisons are from the same quarter in the previous year and are adjusted for both inflation and legislative changes in tax laws.

25. Nicholas W. Jenny, State Tax Revenue Growth Gains Momentum, The Rockefeller Institute State Fiscal News, vol. 4, no. 3, May 2004, p. 2, Figure 2. These growth comparisons are from the same quarter in previous years and are adjusted for both inflation and legislative changes in tax laws. 
26. For a detailed list of state budget-balancing strategies, see the Appendix of: National Association of State Budget Officers, "Budgeting Amid Fiscal Uncertainty: Ensuring Budget Stability by Focusing on the Long Term," 2004, pp. 22-28.

27. National Association of State Budget Officers, "Budgeting Amid Fiscal Uncertainty: Ensuring Budget Stability by Focusing on the Long Term," 2004, p. 14.

28. National Governors Association and National Association of State Budget Officers, The Fiscal Survey of the States, June 2003 (Washington, D.C.: National Governors Association and National Association of State Budget Officers, 2003), p. 14.

29. National Association of State Budget Officers, The Fiscal Survey of the States, December 2001, p. 11 .

30. Ibid.

31. Ibid., p. 12.

32. Elaine Maag and David Merriman, "Tax Policy Responses to Revenue Shortfalls," State Tax Notes, August 4, 2003, p. 366.

33. Ibid., p. 2053.

34. Nicholas W. Jenny and James Orsi, "Budget Balancing Tactics," The Rockefeller Institute State Fiscal News, vol. 3, no. 7 (August 2003), p. 1.

35. The College Board, Trends in College Pricing 2003 (New York: The College Board, October 2003), p. 2.

36. National Governors Association and National Association of State Budget Officers, The Fiscal Survey of the States, December 2001 (Washington, D.C.: National Governors Association and National Association of State Budget Officers, 2001), p. 11. National Governors Association and National Association of State Budget Officers, The Fiscal Survey of the States, November 2002 (Washington, D.C.: National Governors Association and National Association of State Budget Officers, 2002), p. 50. National Governors Association and National Association of State Budget Officers, The Fiscal Survey of the States, December 2003 (Washington, D.C.: National Governors Association and National Association of State Budget Officers, 2003), p. 12. National Governors Association and National Association of State Budget Officers, The Fiscal Survey of the States, April 2004 (Washington, D.C.: National Governors Association and National Association of State Budget Officers, 2004), p. 12.

37. General Accounting Office, Tobacco Settlement: States' Allocations for Fiscal Year 2003 and Expected Fiscal Year 2004 Payments, GAO-04-518 (Washington, D.C.: U.S. General Accounting Office, March 2004), p. 8.

38. Abraham McLaughlin, "Despite gambling's riches, states play cautiously," The Christian Science Monitor (April 22, 2003); Jason White, "States Seek Gambling Fix," Stateline.org (November 22, 2002), visited (5-2-2004) at: http://www.stateline.org/stateline/?pa=story\&sa=show StoryInfo\&id=273131; "Is the Fiscal Crisis Fueling Gaming in the States?" Weekly Bulletin, The 
Council of State Governments, Eastern Regional Conference, issue \#2 (September 10, 2003); Tim Anderson, "Gambling expansion in region has slowed, but states get new round of plans in 2004," Firstline, The Midwestern Office of the Council of State Governments, vol. 11, no. 1 (January 2004).

39. Robert Berner, "State Lotteries Are Coming Up Snake Eyes," Business Week, May 7, 2001.

40. National Governors Association and National Association of State Budget Officers, The Fiscal Survey of the States, June 2003 (Washington, D.C.: National Governors Association and National Association of State Budget Officers, 2003), pp. 2-3, 29, 28.

41. Note: 46 states begin their fiscal year on July 1. The four other states (and the first day of each's fiscal year) are: Alabama (October 1); Michigan (October 1); New York (April 1); Texas (September 1).

42. These 14 states are: Alabama, Alaska, Arkansas, California, Iowa, Louisiana, New Jersey, New York, Oregon, Rhode Island, South Carolina, South Dakota, Washington, Wisconsin. General Accounting Office, Tobacco Settlement: States' Allocations for Fiscal Year 2003 and Expected Fiscal Year 2004 Payments, GAO-04-518 (Washington, D.C.: U.S. General Accounting Office, March 2004), pp. 4-6.

43. Ibid.

44. A few states - California and New York are the biggest — did not, however, shift the risk to the bond holders. These states guaranteed the bond payments with their general fund revenues. Scott Woolley, "The Trouble with Tobacco Bonds," Forbes.com (February 3, 2004), http://www. forbes.com/business/2004/02/03/cz_sw_0202tobacco.html.

45. For details on the Streamlined Sales Tax Project, see: http://www.streamlinedsalestax.org/.

46. Donald Bruce and William F. Fox, "State and Local States Tax Revenue Losses from ECommerce: Updated Estimates," Center for Business and Economic Research, The University of Tennessee, October 2001, p. 1.

47. For a discussion of why and how state revenues grew during the 1990s, see: Donald J. Boyd, "The Future of State Fiscal Conditions: Fiscal Boom, Fiscal Bust, Then What?" Spectrum: The Journal of State Government (Spring 2002), pp. 5-8.

48. For a discussion of the tax side of the structural gap, see: Robert Tannenwald, "Are State and Local Revenue Systems becoming Obsolete?" National Tax Journal, vol. 55, no. 3 (September 2002), pp. 467-489.

49. National Governors Association and National Association of State Budget Officers, The Fiscal Survey of the States, April 2004 (Washington, D.C.: National Governors Association and National Association of State Budget Officers, 2004), p. 1.

50. Nick Samuels, National Association of State Budget Officers, personal communications, June 17, 2004.

51. In the manufacturing sector, technology can improve employee productivity, increase the performance of the product, or create an entirely new product. In health care, technology tends to 
mostly produce entirely new products that contribute to rising expectations for the performance of the health-care sector.

52. Janet Lundy, Benjamin Finder, and Gary Claxton, Trends and Indicators in the Changing Health Care Marketplace, 2004 Update (Menlo Park, Calif.: Kaiser Family Foundation, April 2004), Exhibit 1.3, p. 6. http://www.kff.org/insurance/7031/index.cfm.

53. Janet Lundy, Benjamin Finder, and Gary Claxton, Trends and Indicators in the Changing Health Care Marketplace, 2004 Update (Menlo Park, Calif: Kaiser Family Foundation, April 2004), Exhibit 1.1 ( http://www.kff.org/insurance/7031/index.cfm ); Office of the Actuary, Center for Medicare and Medicaid Services, "National Health Care Expenditures Projections: 2003-2013," Table 1 ( http://www.cms.hhs.gov/statistics/nhe/projections-2003/proj2003.pdf).

54. Table B-46, "Employees on nonagricultural payrolls, by major industry, 1959-2003," The Annual Report of the Council of Economic Advisers (Washington, D.C.: U. S. Government Printing Office, February 2004), pp. 338-339.

55. Ellen O'Brien and Rise Elias, "Medicaid and Long-term Care," The Kaiser Commission on Medicaid and the Uninsured, Publication \# 7089, May 2004, p. 12. States even have flexibility in how they determine the rates they pay for nursing-home care. See David C. Grabowski, Zhanlian Feng, Orna Intrator, and Vincent More, "Recent Trends in State Nursing Home Payment Policies," Health Affairs (June 16, 2004), pp. w4-364-365.

56. Eileen R. Ellis, Vernon K. Smith, and Daivd M. Rousseau, Medicaid Enrollment in 50 States: December 2002 Data Update, Publication \#4155 (Washington, D.C.: The Kaiser Commission on Medicaid and the Uninsured, December 2003), p. 5.

57. Congressional Budget Office, The Budget and Economic Outlook: Fiscal Years 2005 to 2014 (Washington, D.C.: The Congress of the United States, January 2004), pp. 138, 51, 59.

58. National Governors Association and National Association of State Budget Officers, The Fiscal Survey of the States, April 2004 (Washington, D.C.: National Governors Association and National Association of State Budget Officers, 2004), Table 5, p. 5. In contrast, reports NASBO, Medicaid spending from federal funds will increase by just 3.9 percent. Why the difference? Because the onetime fiscal relief that Congress provided the states in FYs 2003 and 2004 included $\$ 10$ billion for Medicaid. Thus, the state-spending base from which FY 2005 spending is calculated is lower than it otherwise would have been, while the federal-spending base was higher.

59. David C. Grabowski, Zhanlian Feng, Orna Intrator, and Vincent More, "Recent Trends in State Nursing Home Payment Policies," Health Affairs (June 16, 2004), p. w4-364.

60. This datum (for the national government's FY 2000) was calculated from Tables 4 and 5 in John Holahan and Brian Bruen, Medicaid Spending: What Factors Contributed to the Growth Between 2000 and 2002? Publication \#4139 (Washington, D.C.: Kaiser Commission on Medicaid and the Uninsured, September 2003), pp. 7, 8.

61. These data (for the national government's FY 2000) were calculated from Tables 7 and 8 in ibid., pp. 10, 11. 
62. Office of the Actuary, Center for Medicare and Medicaid Services, "National Health Care Expenditures Projections: 2003-2013," Table 13. http://www.cms.hhs.gov/statistics/nhe/projections2003/proj2003.pdf.

63. Ibid.

64. For example, see Isaiah J. Poole, "Transportation Money Comes With Strings," CQ Weekly, vol. 62, No. 15 (April 10, 2004), p. 851.

65. Congressional Budget Office, "Cost Estimate: H. R. 49, Internet Tax Nondiscrimination Act," July 21, 2003, p. 1.

66. "Total Outlays for Grants to State and Local Governments By Function, Agency, and Program: 1940-2009," Budget of the United States Government: Fiscal Year 2005: Historical Tables (Washington, D.C.: U. S. Government Printing Office, February 2004), Table 12.3, pp. 272, 266, 269, 271, and 269.

67. Bill Swindell, "Welfare Reauthorization Becomes another Casualty in Congress' Partisan Crossfire," CQ Weekly, vol. 62, no. 14 (April 3, 2004), pp. 805-806.

68. "Total Outlays for Grants to State and Local Governments By Function, Agency, and Program: 1940-2009," Budget of the United States Government: Fiscal Year 2005: Historical Tables (Washington, D.C.: U. S. Government Printing Office, February 2004), Table 12.3, pp. 269 and 272.

69. The Education for All Handicapped Children Act (Public Law 94-142).

70. “The Budget: A Thin Spread,” CQ Weekly, vol 62, no. 6 (February 7, 2004), p. 353.

71. William Driscoll and Howard Fletter, Projected Costs of Implementing the Federal "No Child Left Behind Act" in Ohio, (Columbus, Ohio: Levin, Driscoll \& Fletter, December 12, 2003), pp. vi, vii.

72. James Peyser and Robert Costrell, "Exploring the Costs of Accountability," Education Next, Vol. 4, No. 2 (Spring 2004), pp. 22-29. Paul E. Peterson and Martin R. West, "The Contentious 'No Child' Law II: Money Has Not Been Left Behind," Education Week, vol. 23, no. 7 (March 17, 2004), pp. 72, 58.

73. Lynn Etheredge and Judith Moore, "A New Medicaid Program," Health Affairs (August 27, 2003), p. W3-435.

74. It is impossible to predict what state budgets will look like even several years in the future. We can, of course, attempt to eliminate some of the uncertainty in these projections by basing them on a continuing-services, continuing-taxes premise - on the assumption that states will change neither their policies about services nor their policies about taxes. Yet, even this kind of projection contains uncertainties, for economic factors, such as unemployment, affect both the service and tax levels for any set of policies. Moreover, we know that the states and the federal government will change their policies. But what those revised or new policies might be is strictly a guess.

States could, of course, act to reduce eligibility to the federally required minimum, and the 
federal government could even reduce that minimum. States could also act to reduce their payments to those who are eligible to the federally required minimum, and the federal government could reduce that minimum. But these minimums are set politically, and the growth in the population that is eligible under Medicaid for long-term care will, as it has in the past, act to raise rather than lower these minimums.

75. Drew E. Altman and Larry Levitt, "The Sad History of Health Care Cost Containment as Told in One Chart," Health Affairs (January 23, 2002), pp. W83-W84.

76. Bradley C. Strunk and Paul B. Gtinsburg, "Tracking Health Care Costs: Trends Turn Downward in 2003, Health Affairs (June 9, 2004), p. W4-361.

77. The introduction of private, long-term care insurance could reduce the need for Medicaid to cover these costs for some elderly. Given, however, the current worry about the failure of the BabyBoom generation to plan for retirement, it is unlikely that this trend will have a big impact on Medicaid. For an analysis of the failure of Americans to save for retirement, see: The National Commission on Retirement Policy, The 21st Century Retirement Security Plan (Washington, D.C.: Center for Strategic and International Studies, March 1999), particularly pp. 21-24.

78. Indeed, despite the states' recent budget problems, they appear to not have cut their payments to nursing homes. From a survey of 19 states, the General Accounting Office reports: "State fiscal pressure has not led to major changes in Medicaid Nursing Home payment methods or rates." Kathryn G. Allen, Medicaid Nursing Home Payments: States' Payment Rates Largely Unaffected by Recent Fiscal Pressures, Report GAO-04-143 (Washington, D.C.: General Accounting Office, October 2003), p. 17. One study of state nursing-home payments for 1999-2002 found that "the average Medicaid payment rate for nursing home care experienced a sizable increase over this period after adjusting for inflation..” David C. Grabowski, Zhanlian Feng, Orna Intrator, and Vincent More, "Recent Trends in State Nursing Home Payment Policies," Health Affairs (June 16, 2004), p. w4370. And, in the future, any well-publicized scandal about poor care can create political pressures to raise standards for both nursing-home and community-based care, thus also driving up their costs, which in turn necessitates increases in Medicaid's reimbursement rates.

79. Woodrow Wilson, Constitutional Government in the United States (New York: Columbia University Press, 1980), p. 173.

80. John Holahan, Alan Weil, and Joshua M. Wiener, "Which Way for Federalism and Health Policy? Health Affairs (July 16, 2003), p. W3-326.

81. Lynn Etheredge and Judith Moore, "A New Medicaid Program," Health Affairs (August 27, 2003), pp. W3-438, W3-435, and W3-437.

Robert D. Behn

617-495-9874

redsox@ksg.harvard.edu
Elizabeth K. Keating

617-495-9856

elizabeth_keating@harvard.edu 
The Taubman Center for State and Local Government

John F. Kennedy School of Government

Harvard University

79 John F. Kennedy Street

Cambridge, MA 02138 